\title{
GLOBALISATION AND GLOBAL ECONOMIC GOVERNANCE: CONTEXTUALISING THE INTERPRETATIONS AND THE DEBATE. A REVIEW OF LITERATURE
}

\author{
Arno J van Niekerk ${ }^{1}$
}

Department of Economics, University of the Free State

\begin{abstract}
As one of the most contentious and fascinating issues of modern times, globalisation is a notion in desperate need of conceptual clarification. By creating a theoretical framework and adding historical depth to the analysis of the globalisation thesis, this article attempts first to provide a contextual basis on which to weigh up the credence of globalisation as a process that is transforming the contemporary world economy. Secondly, it highlights the significance of global economic governance in performing both a somewhat regulatory function and a rather stimulating role in the advancement of globalisation. In essence, the article provides a survey of the literature concerned with theories and the historical context for globalisation and global economic governance. The third aim is to emphasise the importance of the debate surrounding globalisation and global economic governance. The evolution and outcome of this debate is seen to be a factor that will make a significant impact on the future direction of the world economy, mainly in terms of helping to shape leading economic thinking.
\end{abstract}

JEL F01, 42

\section{1}

\section{Introduction}

The contemporary era is characterised specifically by global processes that are increasingly determining the greater part of social life. The world economy has internationalised as far as its basic dynamics are concerned in that it is presently dominated by perceived largely uncontrollable market forces. Owing to the growing emphasis on the global context of economic actions, distinct national economies and therefore domestic strategies of national economic management have become less pronounced. As a result, there are continuous efforts to govern the world economy, in many cases with little success (Hirst \& Thomson, 2003: 1).

Many regard the interrelated global processes of globalisation and global economic governance as leading catalysts of change in the world economy (see Ohmae, 1995: 7; Held \& McGrew,
2000: 31; Dicken, 1992: 16). The modernday transformations brought about by these processes have highlighted the need for greater clarity regarding the meaning and disposition of globalisation and global economic governance. The economic doctrines and beliefs of multilateral institutions like the International Monetary Fund (IMF), the World Bank (WB) and the World Trade Organisation (WTO), all central pillars of contemporary global economic governance, are becoming ever more influential in the international environment (Varma, 2002: 1). Governments around the world are increasingly adopting very similar ideologies as the world economy becomes more interdependent and these institutions of governance become more globally authoritative (Castells, 1996: 13). With contemporary globalisation rapidly gaining momentum in a largely liberal global economic order ${ }^{2}$ (especially after the Cold War), it is posing serious challenges to the governance of the world 
economy (Strange, 1996: 71). This emphasises the relationship between these two processes.

Although they are very important determinants of current global developments, globalisation and global economic governance have, in modern literature, become buzzwords so popularised and generalised that their true meaning and application have essentially been diluted. It is therefore necessary for this study to offer greater clarity on the conceptualisation of globalisation and global economic governance. Further, this will add value to the quality of the debate surrounding these two processes. The contentious characters of globalisation and global economic governance have made them core issues of dispute in global affairs, as they affect different countries and groups of people in very different ways (Held \& McGrew, 2000: 30). As a primarily literature study, the aim of this article is twofold: first, to examine and clarify the conceptual interpretation of globalisation and global economic governance; and secondly, to investigate and highlight some of the most pressing issues of debate that give emphasis to the litigious natures of these two processes.

\section{2}

\section{Conceptualisation and context: interpreting global change}

Exploring issues and concerns related to the governance of the world economy demands the question of what exactly needs to be governed. By implication, this requires a classified interpretation of the kind of "reality" or condition in which the contemporary world economy is asserted to be - which is, not surprisingly, an extremely contentious issue. However, before determining this, the meaning of what some consider to be "the defining issue of our time: globalisation" must be investigated (Legrain, 2004: 4, 113). Also known as "the globalisation thesis", the concept characteristically does not attract universal agreement in terms of its meaning and application. Although, historically, various forms of "globalisations" have been identified (see 2.4), the current debate ${ }^{3}$ focuses mainly on the merits and interpretation of contemporary globalisation. As many globalists would argue, contemporary globalisation encompasses a host of interwoven processes, which include: the increasing transnational movement of capital, goods, and people; closer ties via new communications technologies; a rapid turnover of patterns of objects of consumption; a growing awareness of the risks and dangers that threaten the world as a whole. To these can be added a quantitative increase and growth in the importance of transnational political and economic institutions, and globally interlinked civil and political movements. The interpenetration of these processes, both horizontally and vertically, and at the national, sub-national, and transnational levels, is significant.

Contemporary globalisation could be defined as: a process of interaction and integration among the people, companies, institutions and governments involving different nations, a process driven by international trade and investment and aided by information and telecommunications technology (Center for Strategic \& International Studies, 2002: 1). Globalisation could be considered as a progressive increase in the scale of economic and social processes from a local or regional to a world level. In this respect, it is the growing economic dimension of contemporary globalisation that amplifies its impact around the world. Hence, economic globalisation, as part of the broader process of contemporary globalisation, could be defined as: the process by which markets and production in different countries are becoming increasingly interdependent on account of the dynamics of trade in goods and services and flows of capital and technology (Held, 2000: 92, 22). In terms of its implications for global economic governance, trade and productive investment, economic globalisation is becoming increasingly important as a feature of international economic relations. According to globalists, it has transformed the global economic landscape irreversibly involving various measures of political-economic structural changes in the world economy (Gill, 2003: 130). Globalists point to the surfacing of a new global structure whose rules determine how countries, organisations and people operate. In this sense, globalisation is an inevitable trajectory of development, rendering futile any attempts at resisting it. 
Conversely, sceptics contend that the process at work in the world economy is merely that of extensive and intensifying international economic relations, and not globalisation (Hirst \& Thomson, 2003: 4, 7). Although they admit the existence of various degrees of internationalisation, sceptics interpret this process as conjunctural change towards greater international trade and investment within an existing set of economic relations. However, although there are tendencies towards internationalisation, there is still a major role to be played by national-level policies and economic actors (Hall \& Biersteker, 2002: 45). Although this implies some degree of change, with firms, governments and international agencies being forced to behave differently, they can, in the main, use existing institutions and practices to do so. Hence, the sceptical interpretation does not include any structural changes in the world economy.

The distinction between internationalisation and globalisation is also of particular significance to issues relating to global economic governance. Internationalisation reflects a world order dominated by nation-states, with the emphasis consequently on strategic relationships for aid, development and exploitation. This is closely linked to and dependent on autonomous nationstates. In contrast, globalisation reflects global competitiveness between great market blocs and intensified collaboration and competition in the emergence of new regional blocs that are not only economic, but also social and political in nature (Muller et al., 2001: 244). It suggests a less state-centric world order.

As a further dimension of the terminological dispute, sceptics also consider regionalisation to be more closely associated with the present character of the world economy (especially trilateral (TRIAD) regionalisation between the USA, Europe and Japan), than globalisation. Regionalisation (or regionalism or regional integration) is generally understood as an integrative process occurring at a supranational level, but within a certain geographical area (Anderson \& Blackhurst, 1993: 1) and characterised by significant coordinated economic interactions. Importantly, it is seen as the process of reducing the economic significance of national boundaries within a geographic area, which encourages states to work together on a regional scale. In this sense, globalists view regionalisation and globalisation as complementary rather than opposing processes (Lawson, 2003: 110). The basic issue is the relationship between forces of globalisation and forces of regionalisation. From the sceptical viewpoint, regionalism is one possible approach to "a new multilateralism". In this sense, regionalism can be the concept of a world order consisting of regional groupings as the defining element. Sceptics often use this interpretation to challenge the globalisation explanation, thereby suggesting that the process at work in the world economy is actually regionalisation, not globalisation. The sceptical argument is based on the view that the majority of economic activity remains essentially regional rather than truly global in spatial scale. They emphasise a higher degree of regional economic interdependence, economic homogeneity, and coherence (Held \& McGrew, 2000: 157).

In entering the next and most important stage of the debate on the interpretation of globalisation, a key feature is the fact that literature on the subject is confusing in its use of interchangeable descriptions like world economy, international economy, global economy and globalised economy. There is often a "missing link" in descriptions of the world economy as an international/internationalised economy or as a globalised economy. A major source of confusion is that the term "global economy" is very often used in both of these contexts.

An international economy links distinct national markets, while a global economy fuses national markets into a coherent whole (Hall \& Biersteker, 2002: 47). Neither of these, however, should be confused with a fully globalised economy-a different beast altogether. According to Hirst and Thomson (2003: 8), an international economy is one in which the principal entities are national economies. Trade and investment produce a growing interconnection between these still national economies. In this sceptical understanding, the emphasis is on the differential performance of separate national economies and the intensification of linkages between 
them. It ought to be emphasised that countries between which there are larger reciprocal flows of capital and trade (such as the TRIAD) are playing a more important role than others (e.g. low-income countries) in making the global economy appear globalised, when, in fact, it has merely become more internationalised. This becomes clearer, particularly when the global impact of the TRIAD's sizeable multi-national corporations (MNCs) and the large amounts of capital and trade flows they involve is taken into consideration.

On the other end of the spectrum, extreme globalists/globalisers believe that the world economy is in fact a globalised economy - something closely associated with globalism (or new universalism) (Ionov, 2003: 83). In their view, the international economic system becomes autonomised and socially disembedded, as markets and production become truly global. Hence, extreme globalists argue, national economies are completely subsumed and rearticulated into the system by international processes and transactions (Hirst \& Thomson, 2003: 10). As one of the key effects of this, globalists often insist that this leads to a kind of convergence in inequality which contributes to a narrowing of income differentials between countries, thus increasing labour mobility.

A less extreme interpretation would, however, suggest that the world economy is a global economy. This study would prefer to distinguish between a fully globalised economy in which globalisation has served its purpose of fully integrating the world economy, and a global economy: a system that signifies the prevalence of globalisation as still being a process in progress, and where there remains some degree of resistance (in the form of anti-globalisation sentiment, divergence and disintegration). The world economy is indeed more than merely international; it is global in scope but is far from close to being fully globalised (Hirst \& Thomson, 2003: 12). If economic globalisation is associated with the integration of separate national economies, so that the actual organisation of economic activity transcends national frontiers, then a global economy might be said to have emerged. In a global economy, world market forces take precedence over national economic conditions as the real value of key economic variables (production, prices, wages and interest rates) respond to global competition (Held \& McGrew, 2000: 20). Increasingly, this is proving very typical of the current world economy.

In following a less radical globalist view, one can, to this end, conclude by stressing the importance of "systemic economic interdependence" as a differentiating factor. Hirst and Thomson (2003: 10) describe it as the national level being permeated and transformed by the international. In this sense, the study would consider an "international economy" as enclosing a very small measure of systemic economic interdependence, a "globalised economy" as encompassing full systemic economic interdependence, and a "global economy" as possessing a significant degree of it. It is now clear that it is both the global economy and the overarching process of globalisation that have to be governed. There should also be more emphasis on delineating the kinds of governance processes involved. Here the aim is to concisely define and distinguish between global economic governance and global governance. Global economic governance could be defined as: the institutions, norms, practices and decision-making processes from which rules, guidelines, standards, and codes arise in order to manage the world economy (Varma, 2002:3). It includes the private sector, governmental and regional organisations and civil society.

By transcending the state system in similar fashion, global governance could be defined as: a process of political coordination among governments and inter-governmental and transnational agencies (both public and private); it works towards common purposes or collectively agreed upon goals, through making or implementing global or transnational rules, and managing trans-border problems (Held, 2000: 140). Importantly, Held (2000: 141) also emphasised that "it differs dramatically from a concept of world government that presupposes the idea of one central global public authority legislating for humanity". Global governance is based on the acceptance of divided sovereignties, the strengthening of the global rule of law, and the recognition of universally valid values and principles (Messner \& Nuscheler, 1996: 31). 
Whereas global governance refers specifically to the political dimension of governance in the international system $^{4}$, global economic governance refers to the governance of the global economy. Inclusively, global economic governance also forms part of the larger process of global governance, which emphasises the interwoven nature of economic and political issues. In essence, the aim of global economic governance is to provide governance to the economic elements of globalisation. Global governance, though, attempts to perform a governing function in the wider global system, which includes the process of contemporary globalisation. Significantly, both processes operate within the framework of the global system.

\section{3}

\section{Historical identity: globalisation and global economic governance}

The globalisation of economic activity and the governance issues it involves are often thought to have appeared only after the Second World War, and particularly during the 1960s. Although, according to Kilminster (1997: 257), the term "globalisation" first appeared in Webster's Dictionary in 1961, its origins could arguably be traced back to the final stages of the first millennium. The opening period of globalisation is considered to be about $1000 \mathrm{AD}$ when the Moslem world was the nearest approximation to a worldwide political order. Through their far-flung trade the Moslems brought together the major centres of world civilisation (Held \& McGrew, 2000: 49; Modelski, 1972: 86). After 1500 and especially in the latter stages of what is called "archaic globalisations", the Moslem world was strategically outflanked by European naval operations (Bell, 2003: 808). The work of political unification of the world and the expansion of the capitalist world economy now fell to Europe. In one sense, the drive that produced it was a response to the prosperity of the Islamic world and the threat that was perceived to emanate from it (Lawson, 2003: 120). The Europeans not only circumnavigated the globe, but followed up this feat with the establishment and maintenance of a permanent network of worldwide contacts.
While archaic globalisations constituted the first phase of historic globalisation, its second phase consisted of three successive eras: "protoglobalisation" (1600-1800) in which political and economic institutions mutated throughout large part of the world; "modern globalisation" (18001820), which evolved alongside the modern state, nationalism and full-blown industrial capitalism; and "post-colonial globalisation" (1820-1920), characterised largely by a liberal economic order. It included the Industrial Revolution from which growing cross-border trade flows, greater internationalisation ${ }^{5}$ and high growth in the world economy emanated (Bell, 2003: 807).

The subsequent era (1920-present) marked the beginning of what today is called "contemporary globalisation" (Bell, 2003: 807). This era saw, among other things, the formal entanglement of virtually the entire non-Western world in the web of globalisation. Moreover, it particularly signified the rise of the third-world voice in international affairs and, globally, there was growing attention to the notion of "humanity" and the recognition of an "international society" - especially after of the Second World War. Representing the "triumph of capitalism", contemporary globalisation is considered to be the process that brought about an emergent "new global economy" (Lawson, 2003: 119). This new global economy can arguably be recognised as the "latest progression" of contemporary globalisation. It is also considered to be the "third wave" (1980-today) of globalisation, which could be seen as quite distinctive when compared to the "first wave"6 (1870-1914) and the "second wave" (1945-1980) (King \& King, 2005: 208-214). Ohmae (1993: 81) argued that the development of this new global economy should not be considered as merely conjunctural change towards greater international trade and investment within an existing set of economic relations. One demonstration of this is the appearance of an unprecedented "network society" that is radically changing economic relations and is causing a structural transformation in the relations of production and power in the global economy. According to Castells (1996: 93), it is centred on informational capitalism, where the Internet is creating new rules as it induces the networking form. 
It is believed that the true "open world" was born (and globalisation reborn) at Bretton Woods shortly after World War II, signifying the start of contemporary global economic governance (Legrain, 2004: 104; Moore, 1998: 71). Although history played an important role, the existing world order (i.e. its structures and maintenance) is chiefly seen as the result of the decisions taken by the allied powers, during and immediately after the Second World War (Legrain, 2004: 90). Hence, in the presence of 44 countries, a new, post-World War II economic order was consolidated at the New Hampshire Conference in 1944 through the birth of the Bretton Woods twins: the World Bank (then the International Bank for Reconstruction and Development) and the IMF (then the Stabilisation Fund). Together with the International Trade Organisation (ITO) ${ }^{7}$, the world economy was to be organised around these three cornerstones (Södersten \& Reed, 1994: 349; Driscoll, 2004: 59).

Coinciding with the third wave of globalisation, the main institutions of global economic governance arguably started to become more directly involved in the regulation and navigation of global economic activities. It was especially since the 1980 s that the IMF and the World Bank enforced their stronghold within global economic governance through the advent of conditionality. The IMF started with development financing accompanied by structural reform/adjustment programmes (SAPs). The World Bank increased its role in providing loans for balance of payments support to developing countries, together with specific conditions concerning policy reform (Varma, 2002: 9). Notably, the IMF's agenda of anti-deficit and anti-inflationary policies collaborated with the World Bank's efficiency prescriptions for deregulation, privatisation and liberalisation. In addition, the lengthy Uruguay Round (1986-1994) of the GATT Treaty has helped to keep the world trading system both open and at least potentially subject to calculable rules (Hirst \& Thomson, 2003: 15). Hence, corresponding with the expansion of the domains of the IMF and the World Bank, the World Trade Organisation (WTO) was established in 1995 as an intergovernmental negotiating forum (Kreinin, 2006: 141). This was important in strengthening the institution's authority in international trade affairs and also reinforced its function of setting and regulating a code of international trade conduct.

Moreover, if the widespread consensus of the 1950s and 1960s was that the future belonged to a capitalism without losers, securely managed by national governments acting in concert, then the later 1980s and 1990s were dominated by a consensus based on contrary assumptions: that global markets are irrepressible and that the only way to avoid becoming a loser is to be as competitive as possible. Markedly, these were also the neo-liberal ${ }^{8}$ principles on which the views of the IMF, WB, and GATT/WTO were based (Varma, 2002: 12). The global spread of neo-liberal doctrines has everywhere reduced the ability of governments to autonomously formulate economic policies - a clear indication of the interwoven nature of economies around the world and, more importantly, the growing influence of global institutions of governance in international decision-making (Wade, 2000: 488). Finally, the fact that these institutions continue to follow a neo-liberal ideological approach is perhaps the best indication of the complementary role played by global economic governance in globalisation, as both processes advance according to the same principles.

4

\section{Issues of debate: global economic governance and globalisation'}

The contentious natures of both global economic governance and globalisation mean that debate is difficult to avoid. Triggered by abrupt and often baffling changes in the contemporary world economy, a critical dialogue has opened up that attempts to interpret the present form of the world economy, the kind of changes that are taking place, and the modes and effectiveness of contemporary economic governance. The debate is divided mainly between two schools of thought holding almost diametrically opposed views: the globalists ${ }^{10}$ and the sceptics (or traditionalists). A third perspective, that of the transformationists, takes a rather different stance and often places itself in the middle 
ground between the other two. This section will focus on three primary issues of debate, thereby contextualising the arguments of each school of thought. It then outlines the view adopted in the article.

The first issue of debate centres on the matter of whether globalisation should preferably be understood as internationalisation (or even regionalisation). As indicated in section 2.2, globalists are generally proponents of a radical form of globalisation, whereas sceptics are more in favour of internationalisation and regionalisation - especially trilateral regionalisation, which essentially involves the TRIAD countries. Although this issue has largely been dealt with, the transformationist perception remains an important constituent. This view recognises that there is evidence of new forms of intense interdependence and integration that are transforming the international economic system. According to Held (2000: 90), transformationists argue that "international economic relations have changed to such an extent that, while the traditional view of a coherent national economy that can be managed in the interests of domestic objectives is no longer viable, the ubiquity of market forces could also be challenged and resisted, though with great difficulty and only in new forms". They thus interpret this process of global change and transformation as a conditional form of globalisation that is constantly evolving (Held, 2000: 90). In this sense, globalisation should not be understood as an inevitable or a fixed end point.

The second issue of debate concerns the question of whether or not modern-day globalisation is unprecedented. Globalists believe that, even though globalisation has been continuing for centuries, what is happening now is, in many respects, inevitable and historically unprecedented. They assert that globalisation is currently more genuinely global than before. Whereas globalisation was essentially driven by Europe and the Americas in the late $19^{\text {th }}$ century, it now involves Japan, the East-Asian countries, China, Mexico, India and others - countries inhabited by almost two-thirds of the world's population (Legrain, 2004: 108). Also, as part of the Internet-led technology revolution, transport and communications are faster and cheaper than ever, thus further facilitating the expansion of globalisation.

Substantiating their argument, globalists contend that world trade is at record highs and that a wider range of products than before is being traded. Cross-border trade rose to over 25 per cent of world output (GDP) in 2000, which is significantly above the previous peak of 18 percent in 1914 (Legrain, 2004: 107). Products traded are now more technology-driven than previously, not to mention the growth in services too: telecoms, finance, insurance, software and management consultancy. Cross-border services trade, which previously hardly registered in world trade figures, was already in 1997 the fastest-growing component of world trade (contributing 25 per cent of the total) (Obstfeld \& Taylor, 1999: 78; Legrain, 2004: 108-109). In addition, globalists argue that foreign investment is also at an unprecedented high. Assets owned by foreigners increased to 56.8 per cent of world income in 1995, compared to the earlier climax of 17.5 per cent in 1914 (Hoogvelt, 2001: 70). Globalists assert that, although foreign investment was quite substantial a century ago, its impact was limited.

Opposing these contentions, sceptics argue that globalisation is, at any rate, much exaggerated as a distinctly new phenomenon, and they highlight continuities between the past and present. Contending that the current highly internationalised economy is not unprecedented, they do not necessarily involve a move towards a new type of economic system. Hirst and Thomson (2003: 2) emphasise that "it is one of a number of distinct conjunctures or states of the international economy that have existed since an economy based on modern industrial technology began to be generalised from the 1860s". Sceptics claim that, in spite of increases in global flows of trade and investment, these are not substantially different from the economic and social interactions occurring among nations in previous historical times (Held, 2000: 23). In a sense, sceptics argue, the current international economy is less open and integrated than the regime that existed from 1870 to 1914 (the belle époque). The exchange of goods and cultures dates back to early times. Even in the 
$19^{\text {th }}$ century, open trading and liberal economic relations were customary world-wide. Thus, we are witnessing merely a continuation and progression of earlier world trading links.

From the sceptics' viewpoint, the pre-1914 system was genuinely international, tied by efficient long-distance communications and industrialised means of transport. The current technology revolution in communications and information, they argue, has further developed a possibly more complex monetary and trading system, but did not create it. Sceptics also prefer to compare different periods in terms of their openness and integration in order to support their argument (Hirst \& Thomson, 2003: 27). In a study aimed at measuring financial openness, Grassman (1980: 128) used the current account balance to GNP ratios of six leading countries (Great Britain, Italy, Sweden, Norway, Denmark and the US) and found no increase in openness between 1875 and 1975 . There was actually a decline in capital movements for these countries. Measuring it somewhat differently, Howell (1999: 16) (as shown in figure 2.4) found that there was a decrease in openness among the G7 countries from a peak in 1913 (almost 6 per cent), but with a gradual increase after 1970 - reaching 3 per cent only by 1995 . Furthermore, although the net capital flows of the G7, as a percentage of world GDP (at purchasing power parity), increased from 0.34 per cent in 1995 to 0.94 per cent in 2000 , there was a steady decrease in the five-year period after that, falling to 0.86 per cent in 2005 (IMF, 2006: 2-6).

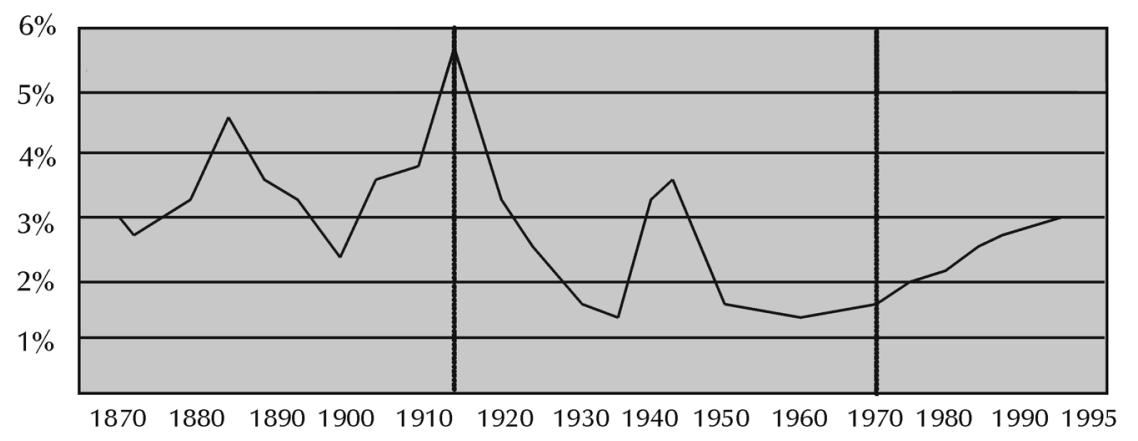

Source: Howell, 1999: 17

Figure 1

International capital flows among the G7 economies as a percentage of GDP, 1870-1995

Also, in a study done by Turner (1991: 17), comparing the pre-1914 Gold Standard period with the 1980s, he found that current account imbalances and capital flows, measured in relation to GNP, were larger before 1914 than during the 1980s. For this reason, sceptics contend that using gross figures for ratios of trade and capital flows relative to output confirms that "openness" was greater during the belle époque than even in the 1990s (Hirst \& Thomson, 2003: 28, 60). All this, argue the sceptics, points to a similar or even greater degree of internationalisation during the earlier period, which suggests that modern-day processes and developments are not unprecedented.

Transformationists assert that there are some new and different issues of economic interdependence particular to the present era. From this perspective, the world economy has certainly not remained unchanged. Owing to fundamental reorganisations in the global economy, they agree that (Held, 2000: 90):

- the world has entered a new phase in the internationalisation of economic activity;

- the present era is one of unprecedented transformation in the patterns of international enmeshment - i.e. complex patterns of reciprocal inter-dependency and integration between economies; and

- the process of transformation designated by the term globalisation is a contingent and historically specific one. 
As economies have become interdependent and technologies connect societies around the world in an interwoven web of interaction, globalisation, according to transformationists, has been progressing intermittently throughout the modern age. They argue, though, that its most recent manifestation signifies a strong qualitative shift towards an unprecedented level of international interdependency, integration and cooperation. Characteristically, transformationists are specifically cautious of the apparent "essentialism" of the globalists and the sceptics. Instead they deliberately propose a via media, asserting that globalisation is a momentous phenomenon, novel in many respects-but there is also nothing that is a longterm historical process shaped by conjectural factors (Bell, 2003: 805-806; Held, 2000: 23). Transformationists therefore agree that globalisation represents a significant shift, but question the inevitability of its impacts.

To this end, it is necessary to highlight that, although the first two issues of debate focused mainly on globalisation, both of them hold important implications for global economic governance. Regarding the first issue vis-à-vis the interpretation of globalisation, the sceptical understanding of internationalisation (as opposed to globalisation) reflects a world order dominated by nation-states (Castells, 1997: 162). From the perspective of global economic governance, this involves a greater degree of emphasis by institutions like the IMF, the World Bank, and the WTO on acting in a way that is supportive of governments' efforts to govern cross-border economic activities more efficiently (thus respecting their sovereignty).

Conversely, the globalist position (and largely the transformationist view, too) insists that globalisation reflects a world order that suggests a lesser role for states and a greater role for regional blocs and global competitiveness. In essence, the governance of global economic activities, seemingly beyond the control and regulation of governments, is at issue here. According to transformationists, there is a distinct need for new forms of supra-national governance, which implies either a greater responsibility for the institutions of global economic governance in regulating cross-border economic activities, or an increased role for wellcoordinated regional governance to perform this function; or even some degree of both (Muller et al., 2001: 244).

As far as the second issue is concerned, although the sceptics are challenging the fact that globalisation is unprecedented, it is important to keep in mind that the pre1914 era was structurally different from the contemporary era. It was characterised by the Pax Britannica system in which Britain owned almost a quarter of the world; and the Gold Standard, with its unique automatic adjustment mechanism, was the monetary regime of the time. The $19^{\text {th }}$ century was a world of unilateral and discretionary policies, while, in contrast, the $20^{\text {th }}$ century was a world of multilateral and institutionalised policy (Legrain, 2004: 113). Thus, by comparison, the globalists (and, in this case, the transformationists, too) perceive the existing world order to be in need of new forms of economic governance and rule owing to the unprecedented nature of globalisation.

The third issue concerns the question first of whether or not it is globalisation that promotes global inequality and second of what the implications for governance are. Although there is clearly some common ground between the three schools of thought about the fact that growing interdependence is associated with a more unequal world, they interpret it and respond differently to it. In the sceptics' view, national factors are considered equally important as determinants of the pattern of global inequality (Gilpin, 1987: 156), if not more so. However, the prospect of moderating, let alone eradicating, the growing North-South divide through coordinated international intervention is decidedly utopian and a categorical mistake, as it could undermine the principle basis of international order (Woods, 1999: 53). In this respect, hierarchy (as headed by the most powerful states), and thereby inequality, is a vital ingredient of the sceptics' understanding of world order, and the basis for effective international governance.

Globalists take issue with this understanding, arguing that, although there has been erosion of old hierarchies, the problem of global inequality can be diminished, if not resolved, 
with concerted global action. Pessimistic globalists in particular consider neo-liberal economic globalisation to be the primary cause of growing global inequality. Alongside world markets and international capital, Hoogvelt (2001: 131) argues that the uneven nature of globalisation is creating a new social division that transcends the old core-periphery organisation of the world economy. Yet optimistic globalists contend that governing the world economy in a manner that would make it less unequal would require exceptionally strong cooperation, involving all stakeholders, including: MNCs, IGOs, governments, multilateral institutions of global governance, and the transnational civil society (Held \& McGrew, 2000: 339).
Transformationists argue that global inequality is illustrated most noticeably by the unprecedented transformation in the patterns of marginalisation of third-world economies. This is resulting in a very uneven and complex relationship between territorial boundaries and transnational forms of economic activity, which is in turn increasing the divide between rich and poor countries. Transformationists are very critical of the current system of multi-layered global governance and view its lack of democratic credentials and legitimacy as serious flaws that can divide nations and exacerbate inequalities (Held, 2000: 175). In their view, the most effective way to minimise global inequality is to reform this system in a manner that would make it more accountable to contemporary principles of democratic governance.

Table 1

Different perspectives on globalisation

\begin{tabular}{|c|c|c|c|c|}
\hline & \multicolumn{3}{|c|}{ SCHOOLS OF THOUGHT } \\
\hline & & Globalists & Sceptics & Transformationists \\
\hline & Conceptualisation & $\begin{array}{l}\text { Globalisation is } \\
\text { occurring via rapid } \\
\text { global flows }\end{array}$ & $\begin{array}{l}\text { Internationalisation } \\
\text { or regionalisation } \\
\text { is occurring, not } \\
\text { globalisation }\end{array}$ & $\begin{array}{l}\text { Globalisation/global } \\
\text { change is recognised } \\
\text { and interpreted in terms } \\
\text { of the transformation of } \\
\text { the global economy }\end{array}$ \\
\hline & Unprecedentedness & $\begin{array}{l}\text { Current globalisation } \\
\text { is historically } \\
\text { unprecedented and is } \\
\text { now more genuinely } \\
\text { global than before }\end{array}$ & $\begin{array}{l}\text { Globalisation is } \\
\text { much exaggerated } \\
\text { as a distinctly new } \\
\text { phenomenon and } \\
\text { current change is seen } \\
\text { as continuities between } \\
\text { the past and present }\end{array}$ & $\begin{array}{l}\text { Global economy has } \\
\text { been fundamentally } \\
\text { reorganised with } \\
\text { some new and } \\
\text { different economic } \\
\text { interdependencies that } \\
\text { can be observed in the } \\
\text { present era, which is } \\
\text { interpreted as a period } \\
\text { of unprecedented } \\
\text { transformation }\end{array}$ \\
\hline 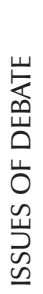 & Global inequality & $\begin{array}{l}\text { Erosion of old } \\
\text { hierarchies as neo- } \\
\text { liberal globalisation is } \\
\text { creating a new social } \\
\text { division }\end{array}$ & $\begin{array}{l}\text { A growing North-South } \\
\text { divide where national } \\
\text { factors are the primary } \\
\text { determinants of global } \\
\text { inequality }\end{array}$ & $\begin{array}{l}\text { The marginalisation of } \\
\text { the } 3^{\text {rd }} \text { World due to } \\
\text { a lack of democratic } \\
\text { multi-layered global } \\
\text { governance which } \\
\text { further divide nations } \\
\text { and exacerbate existing } \\
\text { inequalities }\end{array}$ \\
\hline
\end{tabular}

As far as the view taken in this article is concerned, it recognises that there are arguments for each of the different positions, and there has to be cognisance of them all. While amply recognising both the globalist and the sceptic position in some respects, the study mostly concurs with 
the transformationist assertion. Globalisation is a reality, whether or not people contest it in one way or another. Despite qualitative changes, especially in the post-Cold War era, involving speed and space, globalisation should be seen as a persistently evolving historical process. Although it is possible to differentiate between historic globalisation (1000AD-1920) and contemporary globalisation (1920-today), it should nevertheless be recognised that there exists an important relationship: the former led to the latter.

Moreover, it is essential to note that, although the current global economy is relatively open, it differs in many respects from what prevailed before 1914:

- there is more generalised and institutionalised free trade through the WTO;

- foreign investment is different in its modalities and destinations (owing to a fairly high degree of capital mobility);

- the volume of short-term financial flows is greater, involving a wider range of countries; and

- the international monetary system has also changed quite considerably.

Taking these differences into consideration, direct comparisons between separate periods should be approached with more caution. In this respect, the writer agrees with Hirst and Thomson (2003: 28) that using gross figures for ratios of trade and capital flows might disguise important differences between the two main periods in dispute (pre-1914 and post-1973). Notably, a telling comparative measure of world trade is that used by Hoogvelt (2001: 68, 70), who compared the foreign trade portion ${ }^{11}$ of 1913 (33 per cent) with that of 2000 (43 per cent), and indicated that current world trade is now at a higher intensity level than ever before.

Iit has also become clear that there is a democratic deficit insofar as the institutions of global economic governance are unrepresentative of the world community. The point is: inequality has serious implications for global stability and world order. Globalisation as a process is markedly amenable to influence, a process in which economic and political role players create the structure behind its dynamic and orientation. Incidentally, global governance by corporate capital is arguably the most serious and urgent concern needing consideration, because it reinforces the unevenness that has characterised economic progression from the start of industrialisation. Thus, as Abrahamsson (2003: xviii) states, the two urgent challenges ahead are how to make globalisation more global and global economic governance more representative.

The article, however, acknowledges that there are no easy answers, and that, most importantly, the responsibility rests largely on the shoulders of the developing world to become more proactive in closing the divide between themselves and the first world. Even so, as Held and McGrew (2000: 339) emphasise, the fact is: "whether globalisation, through the combined efforts of the major institutions of global and regional governance, can be given a human face, or whether it will generate a more unruly world, are issues which will dominate the global agenda long into the $21^{\text {st }}$ century".

\section{5}

\section{Concluding remarks}

The study has highlighted the fact that there is a strong connection, especially in the present era, between globalisation and global economic governance. Lawson (2003: 110) emphasises that many discussions of world order and global governance, especially those on economic dimensions, have revolved around the phenomenon of globalisation. Thus, when attention is paid to global economic governance, it would be erroneous to exclude the closelyassociated dynamics of globalisation. The article has shown that these two processes are co-integrated and impact directly on each other. Held et al. (1999: 7) emphasise that "at issue is a dynamic and open-ended conception of where globalisation might be leading and the kind of world order it might prefigure". However, while recognising the abovementioned connection, it is essential to clarify the conceptual meaning and interpretation of globalisation and global economic governance. 
This was the first objective of the study. What became clear is that, apart from distinguishing globalisation from internationalisation and regionalisation, the former, as a process, should also be differentiated from the condition in which the world economy is asserted to be in, as this is a major source of conceptual confusion. In this regard, globalisation is specifically an interpretation of the changes taking place in the world economy, and not a description of what the world economy is perceived to be, i.e. a global economy. Hence, globalisation refers to the integration of national markets in a global economy.

Alternatively, global economic governance refers exclusively to rules and guidelines used by institutions for managing the global economy. As far as the historical identity of the two processes is concerned, the article has called specific attention to the very under-emphasised and valuable role that historic globalisation played in laying the foundation on which contemporary globalisation could evolve, and includes important "learning curves" in the history of world economy. What also became clear was the influential nature of the IMF, the World Bank and the WTO in directing the progression of the global economy and providing scope for globalisation, through neo-liberal doctrines, to progress even further.

As the second objective, the issues of debate emphasised in the article are intriguing because they relate directly to how the two processes of globalisation and global economic governance have been developing, are currently doing so, and will be developing over time - in the real world. The debate is extremely important as it plays a key role in determining the direction in which the global economy is developing. As yet, the debate has, for instance, led to a growing recognition of pleas by the third world regarding global inequality (which is arguably worsened by globalisation) and for more efforts on the part of first-world countries to seek solutions. In the same way, critics of the IMF, the World Bank and the WTO have, with some success, put pressure on these institutions to adjust a significant number of their policies in favour of third-world interests (Stiglitz, 2003: 241). A persistent concern, though, is the third world's growing disenchantment with globalisation and decision-making processes in global economic governance, which threatens to lead to a more nationalistic/insular reaction against these processes.

What clearly arises from the article is the necessity for carrying out further research on both, and for seeking more solutions to the proper governance of the global economy. It is also imperative to open up new dimensions vis-à-vis the debate on globalisation and global economic governance to assist in the search for appropriate answers to the serious imbalances in the global economy.

\section{Endnotes}

1 I would like to thank my promoter, Professor Elsabé Loots, for her invaluable contributions to this article, as well as the two referees for their very constructive comments.

2 Implicitly, global economic governance is the process (or economic governance practice) that takes place within the inclusive framework of global economic order (the condition).

3 Although section 2.3 explores the various issues related to the debate about globalisation and global economic governance, the first issue - that of its conceptual interpretation - is examined here.

4 Note that the terms "international system" and "global system" are, for the purposes of this study, used interchangeably.

5 Although particular attention was earlier paid to the distinction between internationalisation and globalisation, one should keep in mind that internationalisation forms part of globalisation's historical identity, and more specifically, historical globalisation, which preceded contemporary globalisation.

6 The three "waves" of globalisation highlighted here are recognised as the periods in which the process has had its most significant impact on the world economy. For contextual purposes, the first wave is the latter part of historical globalisation, and the next two waves are part of contemporary globalisation.

7 The intended ITO was never actually established at a conference in Havana in 1947-48. It was replaced by the General Agreement on Tariffs and Trade (GATT), which, in turn, was much later (in 1995) superseded by the World Trade Organisation (WTO). 
8 The neo-liberal ideology (also known as pluralism) could be seen as part of modernisation theory and, owing to its neo-classical nature, its central focus is the rule of the market. Its principles are based on market liberalism, and therefore advocate freemarket reforms, which include (among others): privatisation, the deregulation of international capital and trade flows, financial liberalisation, and institutional transformation that complement market-orientated policies (Öniş \& Şenses, 2005: 265).

9 Note that, although the issues of debate emphasised in this section encapsulate some of the most important contentious matters related to globalisation and global economic governance, it does not, of course, include all the various debatable issues that can be related to these two themes.

10 Globalists are, in fact, divided between positive and pessimistic globalists. Whereas the former has a neo-liberal stance and focuses more on the opportunities created by globalisation, the latter is a neo-Marxist version of the globalist position, which accepts the claim that a strong globalisation process has occurred, but thoroughly condemns it (Held, 2000: 22, 89). Unless otherwise indicated, the debate - when referring to the globalist perspective - chiefly emphasises the positive position.

11 The foreign trade portion is measured by the ratio of the volume of world trade (expressed as the sum total of world merchandise exports and imports at current prices) to the volume of world output (GDP). Note: this comparison excludes world trade in services because it is a more contemporary development.

\section{References}

1 ABRAHAMSSON, H. (2003) Understanding World Order and Structural Change, Palgrave Macmillan: New York.

2 ANDERSON, K. \& BLACKHURST, R. (1993) Regional Integration and the Global Trading System, Harvester Wheatsheaf: New York.

3 BELL, D.S.A. (2003) "History and globalisation: Reflections on temporality", International Affairs, 79(4): 801-814.

4 CASTELLS, M. (1996) The Rise of the Network Society, Blackwell: Oxford.

5 CASTELLS, M. (1997) The Power of Identity, Blackwell: Oxford.

6 Center for Strategic and International Studies (2002) What Is Globalisation? New York. Available from: < www.csisglobalisation101.org > [Accessed 26 July 2006].
7 DICKEN, P. (1992) Global Shift: The

Internationalisation of Economic Activity, Paul Chapman Publishing: London.

8 DRISCOLL, M. (2004) "Reverse postcoloniality", Social Text, 22(1): 59-84.

9 GILPIN, R. (1987) The Political Economy of International Relations, Princeton University Press: Princeton.

10 GRASSMAN, S. (1980) "Long-term trends in openness of national economies", Oxford Economic Papers, 32(1): 123-133.

11 GRASSMAN, S. \& LUNDBERG, E. (1981) The World Economic Order: Past and Prospects, Macmillan: London.

12 HELD, D.; MCGREW, A.G.; GOLDBLATT, D. \& PERRATON, J. (1999) Global Transformations Politics, Economics and Culture, Blackwell: London.

13 HELD, D. \& MCGREW, A.G. (2000) The Global Transformations Reader: An Introduction to the Globalisation Debate, Polity Press: Cambridge.

14 HELD, D. (2000) A Globalising World? Culture, Economics, Politics, Routledge: New York.

15 HIRST, P. \& THOMSON, G. (2003) Globalisation in Question, Polity Press: Cambridge.

16 HOWELL, M.J. (1999) "Asia's Victorian financial crisis", IDS Bulletin, 30(4): 1-30.

17 HOOGVELT, A. (2001) Globalisation and the Postcolonial World: The New Political Economy of Development, Palgrave: London.

18 INTERNATIONAL MONETARY FUND (IMF) "World economic and financial surveys", IMF: 1-14. < http://www.imf.org/external/pubs/ft/ weo/2006/01/data/dbadatm.cfm $>$ [Accessed: 3 November 2006].

19 IONOV, I. (2003) "Global history: Key trends and methodology”, Social Sciences, 34(4): 77-90.

20 KILMINSTER, R. (1997) "Globalisation as an emergent concept”, in A. Scott (ed.) The Limits of Globalisation: Cases and Arguments, Routledge: London.

21 KING, P. \& S. KING. (2005) International Economics and International Economic Policy, McGraw-Hill: New York.

22 KREININ, M.E. (2006) International Economics: A Policy Approach, Thomson South-Western: Mason.

23 LAWSON, S. (2003) International Relations, Polity Press: Cambridge.

24 LEGRAIN, P. (2004) Open World: The Truth about Globalisation, Ivan R. Dee: Chicago.

25 MODELSKI, G. (1972) Principles of World Politics, Free Press: New York.

26 Moore, M. (1998) A Brief History of the Future: Citizenship of the Millennium, Shoal Bay Press: Christchurch. 
27 MUlLER, J.; CLOETE, N. \& BADAT, S. (2001) Challenges of Globalisation: South African Debates with Manual Castells, Maskew Miller Longman (Pty) Ltd: Cape Town.

28 MESSNER, D. \& NUSCHELER, F. (1996) Global Governance Challenge: German Politics at the Threshold to the $21^{\text {st }}$ Century, Foundation for Development and Peace: Bonn.

29 OBSTFELD, M. \& TAYLOR, A.M. (1999) Global Capital Markets: Integration, Crisis and Growth, Cambridge University Press: Cambridge.

30 OHMAE, K. (1993) "The rise of the region state", Foreign Affairs, Spring: 78-87.

31 OHMAE, K. (1995) The End of the Nation-State: The Rise of Regional Economics, The Free Press: New York.

32 ÖNIŞ, Z. \& ŞENSES, F. (2005) "Rethinking the emerging post-Washington consensus: A critical appraisal", Development and Change, 36(2): 263-290.
33 SÖDERSTEN, B. \& REED, G. (1994)

International Economics ( $3^{\text {rd }}$ ed.) Macmillan: London.

34 STRANGE, S. (1996) The Retreat of the State: The Diffusion of Power in the World Economy, Cambridge University Press: Cambridge.

35 STIGLITZ, J. (2003) Globalisation and Its Discontents, W.W. Norton: New York.

36 TURNER, P. (1991) "Capital flows in the 1980s: A survey of major trends”, BIS Economic Papers, 30: 14-32.

37 WADE, R. (2000) "National power, coercive liberalism and 'global' finance", in R. Art \& R. Jervis (eds.) International Politics: Enduring Concepts and Contemporary Issues ( $5^{\text {th }} \mathrm{ed}$.) Addison Wesley Longman: New York.

38 WOODS, N. (1999) "Order, globalisation and inequality in world politics”, in A. HURRELL \& N. WOODS (eds.) Inequality, Globalisation and World Politics, Oxford University Press: Oxford. 